\title{
Reviews: \\ Komodo National Park as a conservation area for the komodo species (Varanus komodoensis) and sustainable ecotourism
}

\author{
AKMALIA IMBI FEBRIYANTI HIDYARKO ${ }^{1}$, ALDILA CAHYA GAYATRI ${ }^{1}$, VIRA AINU RIFA ${ }^{1}$, AYU ASTUTI $^{2}$, \\ LIA KUSUMANINGRUM ${ }^{1,3}$, YOSEP S. MAU ${ }^{4}$, HERU RUDIHARTO ${ }^{5}$, AHMAD DWI SETYAWAN ${ }^{1,6, \%}$ \\ ${ }^{1}$ Department of Environmental Science, Faculty of Mathematics and Natural Sciences, Universitas Sebelas Maret. J1. Jend. Urip Sumoharjo No. 179, \\ Surakarta 57128, Central Java, Indonesia.Tel.: +62-271-663375, ’email: volatileoils@ gmail.com \\ ${ }^{2}$ Biodiversity Study Club, Department of Biology, Faculty of Mathematics and Natural Sciences, Universitas Sebelas Maret. Jl. Ir. Sutami No. 36A, \\ Surakarta 57126, Central Java, Indonesia \\ ${ }^{3}$ Environmental Science Research Group, Universitas Sebelas Maret. Jl. Ir. Sutami No. 36A, Surakarta 57126, Central Java, Indonesia \\ ${ }^{4}$ Department of Agrotechnology, Faculty of Agriculture, Universitas Nusa Cendana. Jl. Adisucipto, Penfui, Kupang 85001, East Nusa Tenggara, \\ Indonesia \\ ${ }^{5}$ Bukit Barisan Selatan National Park. Jl. Ir. H. Juanda No.19, Terbaya, Kota Agung, Tanggamus 35384, Lampung, Indonesia \\ ${ }^{6}$ Biodiversity Research Group, Universitas Sebelas Maret. J1. Ir. Sutami No. 36A, Surakarta 57126, Central Java, Indonesia
}

Manuscript received: 7 March 2021. Revision accepted: 10 June 2021.

\begin{abstract}
Hidyarko AIF, Gayatri AC, Rifa VA, Astuti A, Kusumaningrum L, Mau YS, Rudiharto H, Setyawan AD. 2021. Komodo National Park as a conservation area for the komodo species (Varanus komodoensis) and sustainable ecotourism. Intl J Trop Drylands 5: 27-40. Komodo National Park (East Nusa Tenggara Province, Indonesia) is a biodiversity conservation area with the main aim to protect the original habitat and remaining population of Komodo dragon species (Varanus komodoensis Ouwens, 1912). Nonetheless, the area also has great potential as one of the objects of tourist attraction. The purpose of this study is to see the sustainable function of conservation and tourism in Komodo National Park. Komodo National Park covers land area of more than 603 square kilometers and 1214 square kilometers of marine habitat. The land habitats have 277 species of animals while the marine habitats have 253 species of corals, more than 1,000 species of fish, and 25 species of whales and dolphins. One of the main attractions of the Komodo National Park area is the ancient giant reptile of the Komodo dragon (Varanus komodoensis). The tourism management of Komodo National Park (KNP) is currently done through an ecotourism approach. The tourism zone is determined based on part of the Komodo National Park which has the potential for land and marine tourism with a diversity of flora and fauna. The participation of communities living around KNP in the ecotourism business can increase local economics and conservation awareness; as well as their participation in conservation. Meanwhile, the factors that hinder community participation in tourism development are limited budget, apathy and low public awareness, fluctuations in tourist visits, and difficulties in marketing ecotourism products.
\end{abstract}

Keywords: Ecotourism, Komodo National Park, protected areas, tourism zone

\section{INTRODUCTION}

Komodo Island is one of the islands in the East Nusa Tenggara Province, Indonesia. This island is the habitat of the Komodo dragon (Varanus komodoensis Ouwens, 1912) (Figure 1) (Kurniawati and Ratunnisa 2016). The island is named as Komodo Island (Pulau Komodo) after the animal was discovered in 1910. Komodo is an endangered animal with a population of less than 4000 in the wild. As an effort to protect Komodo dragons, in 1980 a conservation area was established on Komodo island which is now known as the Komodo National Park (Situmeang 2012). Komodo National Park is located in Komodo Sub-district, West Manggarai District, East Nusa Tenggara Province, Indonesia (Figure 2) (Gibson et al. 2020).

The determination of the Komodo National Park Conservation Area was based on the Decree of the Minister of Forestry No. 172/Kpts-II/2000 dated June 29, 2000 with a total area of 173,300 ha, of which the water area is $114,801 \mathrm{Ha}$ and the land area is $58,499 \mathrm{Ha}$. The zoning of
Komodo National Park was approved based on the Decree of the Director-General of Forest Protection and Nature Conservation No. SK.21/IV-SET/2012 concerning Zoning of Komodo National Park (Ministry of Forestry 2012). Komodo National Park consists of several small and medium islands.

The Komodo National Park area is divided into several zones, including the core zone (34311 ha), jungle zone (66921.08 ha), marine protection zone (36308 ha), land tourism utilization zone ( 824 ha), marine tourism utilization zone (1584 ha), land traditional use zone ( 879 ha), marine traditional use zone (17308 ha), pelagic special use zone (59601 ha), special zone for traditional community settlement (298 ha) (Figures 2 and 3). The division of the zone is based on land function, land use and land potential. For example, tourism zones are defined based on the part of the national park that has land and sea tourism potential (Walpole et al. 2008). Nonetheless, there is one potential zone that is not yet designated, namely the community business potential zone. This zone becomes 
important for community development to support tourism if the Komodo National Park area develops rapidly to become a tourism center (Adil 2018).

The Indonesian tourism industry continues to experience rapid industrial development. Tourism is one of the potential sectors that influence economic development such as job creation for local residents, infrastructure development, and as a medium in understanding the culture of an area (Sokhanvar et al. 2018). In order to achieve maximum sustainability and tourism goals, the management of tourism is an important thing to pay attention to (Gabur and Sukana 2020). Ecotourism is one part or sub-sector of the tourism industry which attracts many domestic and foreign tourists (Yilma et al. 2016). The concept of ecotourism is to combine environmental aspects with sustainable tourism. Ecotourism aims to maintain the use and conservation of natural resources, especially biodiversity (Imran 2012). Ecotourism is a responsible concept for protecting the environment and the living things that live around protected areas (Safaradabi 2016). Ecotourism can act as a model for sustainable development for local governments and local communities that have economic, social and ecological benefits (Nurinsiyah et al. 2015). Ecotourism will create a stable situation by following a philosophy of life based on intrinsic and inner values (Safaradabi 2016). Ecotourism creates an environmental management tool for local governments while providing an alternative source of income for local residents and avoiding unsustainable land use (Koens et al. 2009). Ecotourism is related to local government policies to preserve the environment and culture of protected areas (Seifi and Ghobadi 2017). There are several criteria to make an area into an ecotourism area, namely: (i) the area must have a special uniqueness and cannot be found anywhere else; (ii) the readiness of the local community to participate; (iii) the legal status of the area should be clear; (iv) accommodation and other supporting facilities are available (Pratiwi et al. 2017). In the concept of ecotourism, attraction is one of the important things. Attraction is the main factor that influences tourists to get pleasure and experience in visiting tourism (Ramadhan 2016).

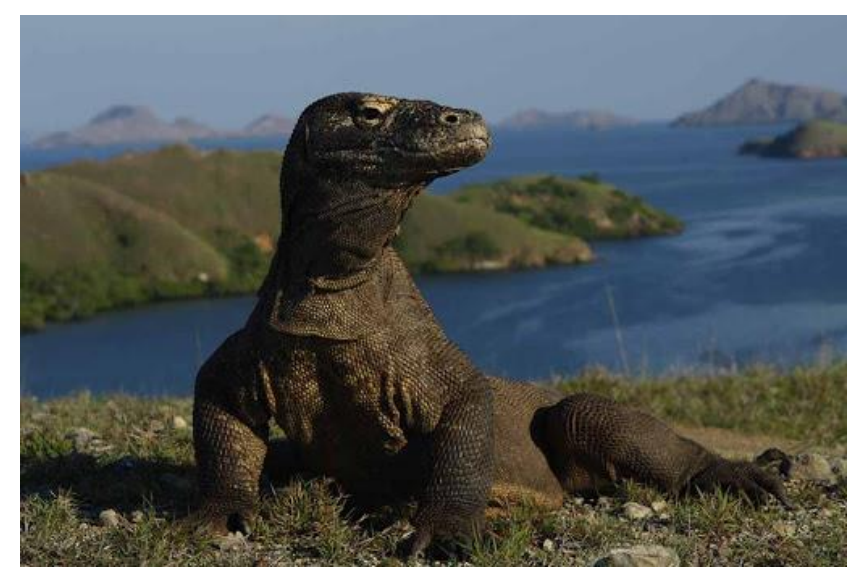

Figure 1. Komodo (Varanus komodoensis) in Komodo National Park, Indonesia (KSDAE 2021)
The Komodo National Park area consists of three large islands, namely Komodo Island, Rinca Island and Padar Island (Jamu 2014). Padar Island is the third-largest island and located between Rinca Island and Komodo Island (Komodo National Park Hall 2018). Each island has its own attractiveness (Parta 2019). Komodo Island has tourist attractions in the form of Loh Liang, Rinca Island with Loh Buaya and Padar Island with South Padar and Long Beach located in the western part of Padar Island and several small islands around it. Nonetheless, the main attraction of ecotourism of Komodo National Park is the Komodo dragon itself, spread across several islands, including Komodo Island, Rinca Island, and Padar Island. Considering that Komodo dragon is an endangered animal, the tourism management of Komodo National Park is currently using an ecotourism approach. The resource management strategy used in the implementation of tourism on Komodo Island should refer to conservation principles, so that the preservation of Komodo can be maintained and tourism activities can be carried out in a sustainable manner (Suryani et al. 2016).

The ecotourism potential in Komodo National Park is in fact very competitive at global level by bringing more than 50,000 people per year with $85 \%$ of them are foreign tourists (Iriyono et al. 2013). The high level of tourism activities in this national park seems to affect the existence of Komodo dragon population (Ardiantiono et al. 2018). This is evidenced by the declining distribution and population of Komodo dragons in the last three decades. For example, data from the Komodo National Park office (2018) showed that the population of Komodo dragons on Padar Island remains seven. In addition to tourism, population decline of deer as the main prey has also been another factor causing the decline in the Komodo dragon population (Jessop et al. 2007). With this population decline, special attention and conservation efforts are needed for Komodo dragons.

\section{PROTECTED AREA - KOMODO NATIONAL PARK}

Act No. 26 of 2007 concerning Spatial Planning, which was followed up by Government Regulation No. 26 of 2008 concerning National Spatial Planning, stated that protected area is an area designated with the main function of protecting environmental sustainability which includes natural resources and artificial resources, as well as the historical and cultural values of the nation, in the interest of sustainable development. A protected ecosystem conserves potential germplasms which can be developed to meet human needs in the future (Anshori 2005). Protected areas consist of national parks, wildlife sanctuaries, nature reserves, nature conservations and cultural heritages, areas prone to natural disasters, geological protected areas, and other areas (Mokodongan et al. 2014). Based on the IUCN there are several categories of protected areas, namely: 1) strictly protected areas for nature protection; 1a) protected areas for research; 1b) protected area for nature conservation, 2) protected area for ecosystem protection and recreation, 3) protected area for conservation, 4) 
protected area for conservation management, 5) for tourism and landscape, 6) preservation of natural resources for ecosystem sustainability. Protected area might serve as attraction for tourism, but without disturbing the function and environmental sustainability. The development of attractions in protected area can be in the form of green open spaces (Darsiharjo et al. 2016). The Komodo National Park area as a form of national park functions to protect the ecosystem and biodiversity while to some extent it might be utilized for tourism purposes.

The Komodo National Park area and its surroundings are one of the areas designated as national strategic areas (Kawasan Strategis Nasional/KSN) as stated in Government Regulation No. 13 of 2017 concerning National Spatial Planning. The determination of this area is because the Komodo National Park and its surrounding areas located on Flores Island and Sumbawa Island have the potential and strategic importance to be developed as a driver of the national economy and protection of biodiversity. The development of the area, an agglomeration of natural and socio-cultural wealth located in West Manggarai and Bima districts, is expected to provide important resources as part of Integrated Coastal Area Management. The National Strategic and Important Values that have been outlined in the National Strategic Area Zoning Plan (RZ KSN) of Komodo National Park are also expected to provide sufficient water resources and legal certainty to minimize problems/conflicts on the use of water areas in the Komodo National Park Area KSN and its surroundings. Conservation Areas and Protected Biota Conservation areas within the Komodo National Park include: (i) Banta Island Regional Water Conservation Area which has been established by the Decree of the Governor of NTB No 523-505 dated 25 May 2016; (ii) Reserve for the Coconut Island Regional Water Conservation Area that has been allocated in the Perda RZ WP3K NTB document; (iii) Reserve for Longos Island Regional Water Conservation Area that has been allocated in the Perda RZ WP3K NTT document; (iv) Komodo National Park which has been established by the Decree of the Minister of Forestry and Plantations No. 172/KPTS-II/2000 (Suraji et al. 2020).

Protected areas that are used as tourist areas such as Komodo National Park must be able to maintain and accommodate the things that become criteria of protected areas. Nonetheless, non-conservation and tourism uses are also allowed to some extent particularly if there is an enclave area with historical use by indigenous communities. For example, Papagaran Island is one of the small islands located within the Komodo National Park area, and as a traditional use zone in accordance with the 25 years management plan initiated by the Government of the Republic of Indonesia through the Komodo National Park Center (BTNK). More than 280 fishermen households depend on coastal resources around the small island (Sudaryanto and Herdiansyah 2018).

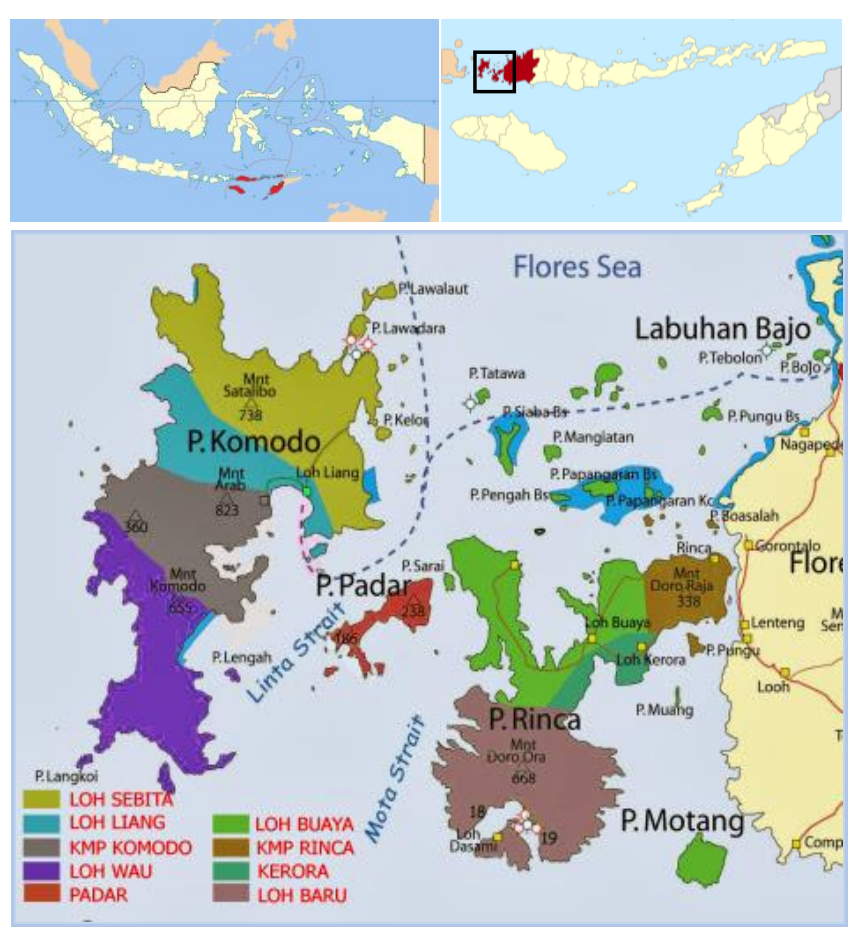

Figure 2. Map of the Komodo National Park area, Indonesia. Source: pariwisata-tourisme-flores.blogspot.com

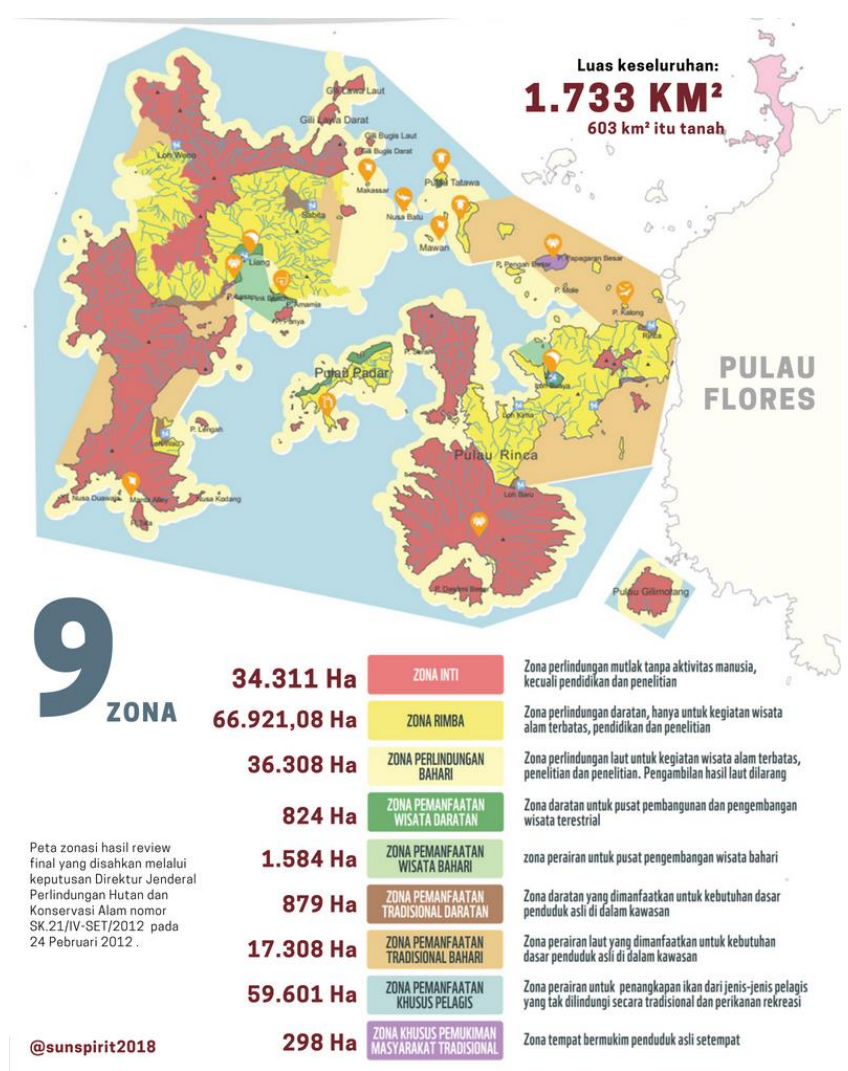

Figure 3. Komodo National Park zoning, Indonesia. Source: sunspiritforjusticeandpeace.org 
In accordance with the mandate of the Law of the Republic of Indonesia No. 32 of 2014 concerning Marine Affairs Article 42, as well as maritime and marine policy directions and listed in the 2015-2019 RPJMN, considering that the Komodo National Park area is one of the national strategic areas, it is necessary to prepare a Presidential Regulation on Komodo National Park KSN Zoning Plan (Suraji et al. 2020). Regulations regarding zoning are provisions that regulate the use of space and elements of control that are prepared for each designation zone to conform to its designation (Budhianti 2019).

As stated above, Komodo National Park is divided into 9 zones, with each zoning has a different area function. The core zone is a zone that focuses on area conservation (Oktaviani et al. 2021). There should be no human activities in the core zone, except activities related to research and education. The jungle zone is a protection zone, this zone can be used for limited nature tourism activities, research and education. The marine protection zone is a zone that focuses on marine/water conservation, in this zone limited natural tourism activities are allowed, but no marine product collection activities are allowed. Land tourism utilization zone is an area used for a mainland natural tourism center. Marine tourism utilization zone is an area that is used as a center for marine natural tourism. There is a favorite destination for scuba divers or snorkeling in this zone because it has tourist attractions such as coral reefs, sharks, and various other marine biotas (Kusnanto et al. 2018). Traditional land and maritime use zones, zones used for accommodation activities for the basic needs of indigenous people with special utilization rights permitted by the Head of the National Park Authority. In the traditional marine use zone, marine products can be harvested using environmentally friendly tools (fishing rods, huhate, and umbrellas). The special pelagic zone is a zone in which fishing activities and other unprotected marine products can be taken as well as tourism/recreational activities. Furthermore, the special settlement zone, the zone used to settle the natives.

These zones are spread over 3 major islands, namely Komodo Island, Rinca Island and Padar Island. Komodo Island is the largest island, this island is mostly a core zone and a jungle zone. The second largest island in the Komodo National Park area is Rinca Island. This island has a beauty that is no less interesting than Komodo Island. In addition, Rinca Island has several species of animals that are not found on Komodo Island such as the Rinca rat (Rattus rintjanus), Wild horse (Equus caballus) and Long-tailed macaque (Macaca fascicularis). Rinca Island has also a savanna area which is the habitat of various wild animals such as deer, buffalo, horses, all of which are a source of food for the Komodo dragon. Limiting the distribution of settlements in the savanna area is an action to maintain the survival of the Komodo dragon (Adil et al. 2017). The mainland of Padar Island is divided into 3 core zones, namely the core zone in the small Padar and Batubilah island, the jungle zone at several points in the south and west of Padar Island, and the northern, eastern and southern land tourism utilization zones. The waters in the Padar Island area as a whole are included in the marine protection zone.

\section{TOURIST ATTRACTION}

Tourism potential is the most important component for developing tourist areas and maintaining tourism resources (Rijal et al. 2020). The ecological carrying capacity aspect is the ability of the environment to provide a tourist attraction (Butarbutar and Soemarno 2013). Tourist attraction is everything that has uniqueness, beauty and value in the form of a diversity of natural, cultural and man-made wealth that is the target or purpose of visiting tourists (Susila and Pramono 2020). Komodo National Park has two kinds of attractions, namely marine tourism attractions and mainland tourist attractions. Marine tourism attractions include snorkeling, diving, canoeing, and others. Meanwhile, activities on the land include animal watching, hiking and camping. Animal watching is a form of tourist attraction that comes from the diversity of natural wealth in the form of fauna or endangered animals used as objects that can attract visitors. The animal watching tourist attraction is distinct from other attractions because it includes various species in different locations and pays attention to the typology of visiting tourists (Tapper 2006). Animal watching pays attention to typology to maintain animal quality and protect animals in vulnerable areas. Animal watching tourism product is a tourism product that is used to distinguish the animals watched from their natural habitat. Tourism products can be interpreted as interrelated components and support tourism activities (Gabur and Sukana 2020).

There are several tourist attractions in Komodo National Park, especially in Loh Liang, Loh Buaya and Pandar Island (Figures 4-6) as described below.

\section{Loh Liang on Komodo Island}

One of the tourist destinations that are the mainstay of Komodo Island is Loh Liang. Loh Liang is the main welcoming area for tourism activities (Mayasari 2006). Loh Liang is dominated by savanna ecosystem consisting of 5 valleys, including two broad valleys, namely the Banunggulung valley and the Poreng valley (Muslich and Priyono 2005). At this location, visitors can see directly the Komodo dragons and local plants that grow in the area (Ahmad and Yunita 2019). Besides being able to see Komodo dragons directly, visitors can also observe deer, wild boars, and birds as well as climbing. In Loh Liang there is also mangrove area where tourists can watch sea birds (Butchart et al. 1996).

\section{Loh Buaya on Rinca Island}

Loh Buaya is one of the tourist areas in KNP. Loh Buaya has the main attraction because of its authenticity and natural beauty, especially the savanna ecosystem and underwater panorama. Savanna is the dominant ecosystem in Loh Buaya. In this ecosystem, tourists can directly observe Komodo dragons, deer (Cervus timorensis), Longtailed macaque (Macaca fascicularis), Wild horses (Equus caballus) and buffalo (Bubalus bubalis) (Garsetiasih 2001). The attractions of marine tourism in Loh Buaya are fishing, snorkeling, diving and canoeing (Lun 2016). In addition, 
tourism activities that can be carried out are observing wildlife and observing bats (Kodir et al. 2019).

\section{Padar Island}

Padar Island is a small island located between Komodo Island and Rinca Island. Padar Island has two main attractions, namely South Padar and Long Beach, located west of Padar Island. Padar Island is the third largest island after Komodo Island and Rinca Island (Leha et al. 2021). Padar Island has become an UNESCO world heritage because it is part of the Komodo National Park (Narulita et al. 2012). Padar Island is included in the jungle zone and the tourism activities are limited. The basis of the attractions of Padar Island is the beauty of the natural scenery both on land and at the sea. Tourism activities in Padar Island are divided into two parts, in South Padar in the form of trekking, adventure and bird watching. Meanwhile, in Padar Barat, tourism activities include snorkeling and swimming at Long Beach.

\section{KOMODO NATIONAL PARK BIODIVERSITY}

Komodo National Park applies ecotourism-based tourism management (Liestiandre et al. 2019). Apart from tourism, other activities carried out in the Komodo National Park area are related to the conservation of the Komodo dragon and other biodiversities (Ziku 2015). Komodo dragon is an ancient reptile that has high conservation value and is included in the flagship species of KNP. The Komodo dragon is the largest lizard in the world with prominent conservation value as a species that protects the ecosystems of southeastern Indonesia (Ariefiandy et al. 2015). Species with limited distribution will decline rapidly because they are very sensitive to global change processes (Ariefiandy et al. 2013; Davis et al. 2016). Komodo dragons are also top predators and have isolated island distributions, making them very sensitive to environmental changes (Ariefiandy et al. 2021). The Komodo dragon has small home range with isolated populations with only about $80 \mathrm{~km}^{2}$ of potential Komodo dragon habitat is protected and conserved (Jones et al. 2020). The limited range of Komodo dragons causes the Komodo dragon to be categorized as "Vulnerable" by the World Conservation Union (IUCN 2014). Given the high risk of extinction this species faces, a multidisciplinary approach is needed in the conservation program that addresses the species itself and its habitat (Estoque et al. 2012).

The Komodo dragon is also included in Appendix I of the Convention on International Trade in Endangered Species of Wild Fauna and Flora (CITES). CITES is a regulation that deals with issues such as exploitation of wild organisms for profit; trade-in illegal goods; killing or capturing wild animals; and the use of animals for purposes deemed repugnant. Certain species included in the appendix to the CITES are those vulnerable to extinction. It is necessary to conserve and apply trade restrictions as a contribution to international conservation (Hutton and Dickson 2000). The Komodo dragon is included in
Appendix I due to its demographic decline and limited distribution. The Komodo dragon sales are about $0.0010 \%$ of the global sales percentage (Pernetta 2009). The level of sales of live Komodo dragons tends to be higher than the trade of komodo skins (Murphy et al. 2002).

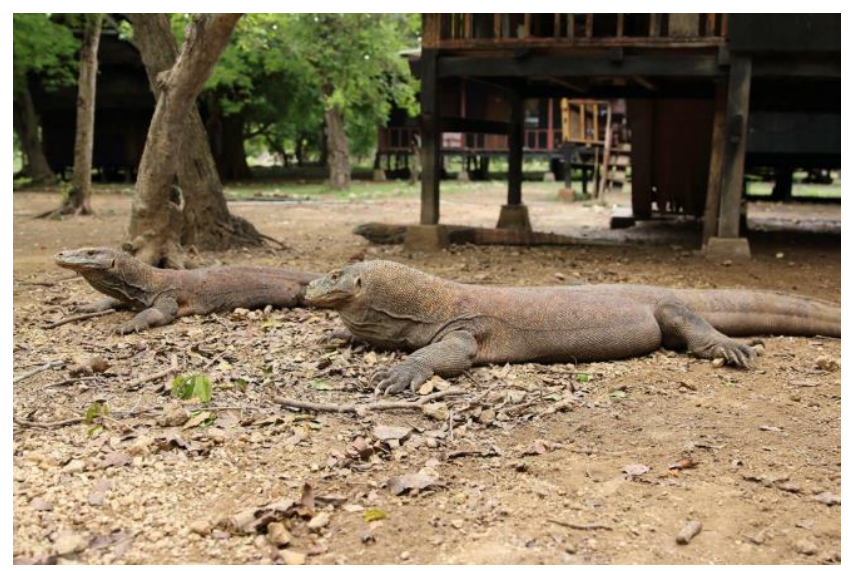

Figure 4. Loh Liang in Komodo National Park, Indonesia. Source: www.getlostsafely.com

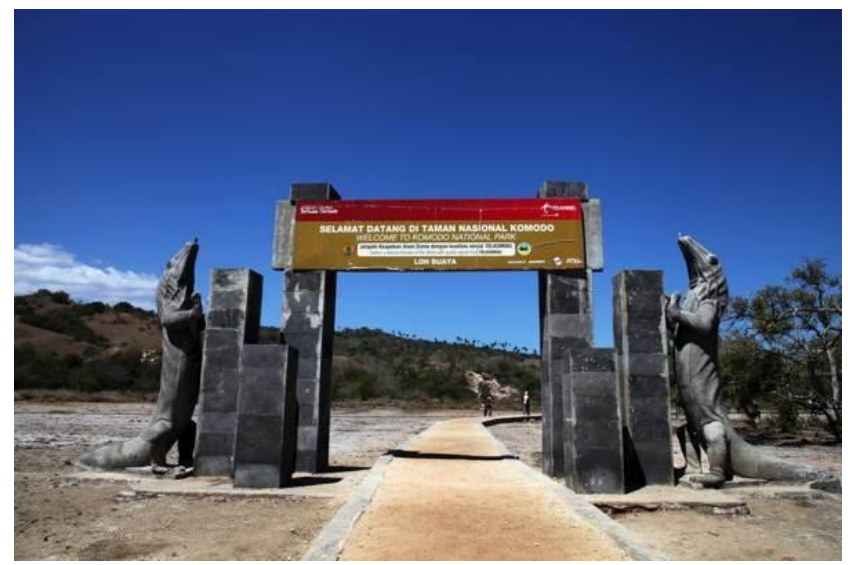

Figure 5. Loh Buaya in Komodo National Park, Indonesia. Source: portal.manggaraibaratkab.go.id

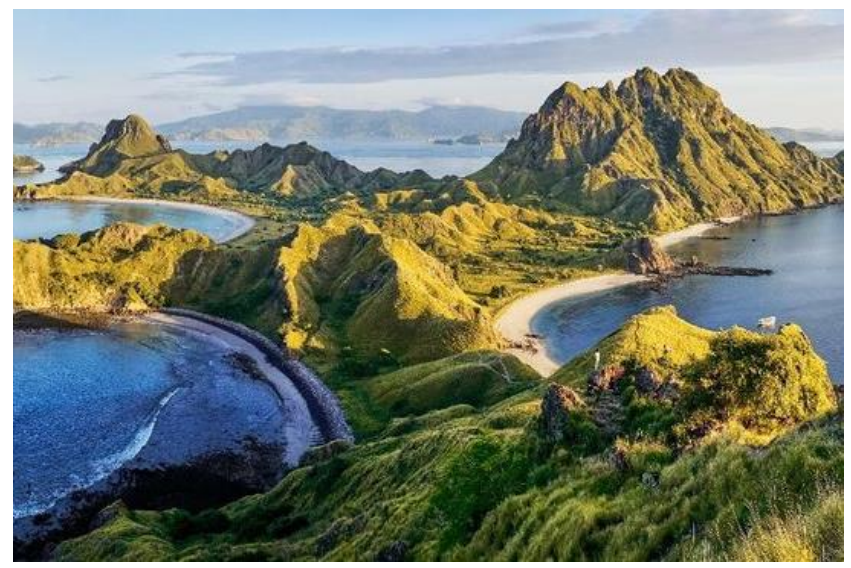

Figure 6. Iconic scenes of Padar Island in Komodo National Park, Indonesia. Source: www.cnnindonesia.com 
The Komodo dragon is endemic to five small islands in eastern Indonesia, with four populations in Komodo National Park and several fragmented populations on the larger Flores Island (Ariefiandy et al. 2013). Komodo dragon is top predator with the dominant prey species include deer, wild boar, and buffalo (Bull et al. 2010). Anthropogenic activities such as poaching can reduce the Komodo dragon population outside and inside the Komodo National Park area. Ecotourism is deemed the right solution to protect endangered species that will become extinct (Portia and Ulfah 2019).

In addition to Komodo as a flagship species, the Komodo National Park area that is dominated by grassland (savanna) also has other diverse fauna species. There are 277 species of animals found that currently living inside the park. Those animals are believed to be a mix of Asian and Australian biodiversity. Among those numbers, there are 32 species of mammals, 128 species of birds, and 37 species of reptiles. The marine habitats found in the park are mangrove forests, seagrasses, and coral reefs ecosystem. There are 253 species of corals that have been successfully identified. More than 1,000 species of fish live in that ecosystem (KSDAE 2021) and 25 species of whales and dolphins (Putra and Parno 2018). Some interesting animals are shown in Figures 7-11.

Mammals that are relatively abundant in the Komodo National Park area are Long-tailed macaque (Macaca fascicularis) and Asian palm civet (Paradoxurus hermaphroditus) (Jessop et al. 2006). The long-tailed monkey is a semi-arboreal, omnivorous species and is distributed throughout the islands of Southeast Asia to mainland Asia (Supriatna and Wahyono 2000). Other mammal species such as Javan rusa (Cervus timorensis), Wild boar (Sus scrofa), Rinca rat (Rattus rintjanus), Water buffalo (Bubalus bubalis) and Wild horse (Equus caballus) and Asian wild dog (Cuon alpinus) (Djuanda 2009). Komodo National Park found about 18 species of herpetofauna. Among them were 2 species of amphibians, namely Fejervarya cancrivora and Kaloula baleata (Kennedi et al. 2020) and 16 species of reptiles, including Indian cobra (Naja naja), Russell snakes (Viperia russeli), White-lipped pit viper (Trimeresurus albolabris), pythons (Python sp.), sea snake (Laticauda colubrina), gecko (Gekko sp.), Hawksbill turtle (Eretmochelys imbricata), Green turtle (Chelonia mydas) and lizards (Scincidae, Dibamidae, Varanidae). There are also several species of birds including, Christmas frigatebird (Fregata andrewsi), Eurasian whimbrel (Numenius phaeopus), Red-backed buttonquail (Turnix maculosa), Zebra dove (Geopelia striata), Rainbow pitta (Pitta australis), Pied bush chat (Saxicola caprata), Helmeted friarbird (Philemon buceroides), Black-naped oriole (Oriolus chinensis), Orange-footed scrubfowl (Megapodius reinwardt), Bluetailed bee-eater (Merops philippinus), Yellow-crested cockatoo (Cacatua sulphurea) and Green junglefowl (Gallus varius). The most common species encountered is Large-billed crow (Corvus macrorhynchos). Crows are vultures that have an important role in maintaining the balance of the ecosystem. Based on estimates, more than
1000 small yellow-crested cockatoos were found on Komodo Island (Reuleaux et al. 2020). There are also 5 species of eagles found in the Komodo National Park area, namely White-bellied sea eagle (Haliaeetus leucogaster), Brahminy kite (Haliastur indus), Black-winged kite (Elanus caeruleus), Bonelli's eagle (Hieraaetus fasciatus) and Spotted kestrel (Falco moluccensis).

Meanwhile, the species of fish found in the waters of Komodo National Park include Cheilinus fasciatus, Scarus flavipectoralis, Ctenochaetus striatus, Scolopsis margaritifera, Hemigymnus melapterus, Mobula birostris, Scarus dimidiatus, Ctenochaetus binotatus, Pentapodus trivittatus, Parupenetic Zebrasoma scopas (Indrawati et al. 2020). In addition, the diversity of fauna such as reef fish is also abundant. The existence of coral reefs in the waters of Komodo National Park is very useful for increasing the sustainability of marine ecosystems. Coral reefs provide ecosystem services in the form of habitats for breeding, shelter and large wave barriers. In addition to ecological functions, coral reefs are a tourism attraction so that they will have an economic impact on the community (Witomo et al. 2020). Among the fauna species found above, there are 4 protected fauna species, namely, Komodo dragon (Varanus komodoensis), Manta rays (Mobula birostris), Great white shark (Carcharodon carcharias), and Green sea turtle (Chelonia mydas).

The diverse ecosystem of Komodo National Park, including savanna (predominantly, 80\%), upland forest, monsoon forest and mangrove forest is one of the factors contributing to its high potential for biodiversity (Borchers 2008). Savannahs and savanna grasslands occupy drier areas. Savanna is a grassland that is used by Komodo dragons (Sutomo 2020). The palm tree (Borassus flabellifer) is the most dominant and distinctive species in the savanna ecosystem. In addition, there are four species of grass in the savanna, namely Themeda arguens, $T$. frondosa, $T$. intermedia and $T$. gigantea. In addition to the 4 dominant grass species in the savanna of Komodo National Park, there are several other grass species, such as Setaria adhaerens, Chloris barbata and Heteropogon contortus. However, the dominant species is the Themeda arguens which account for $80 \%$ of the savanna cover. Several other plants in Komodo National Park include rattan (Calamus sp.), bamboo (Bambuseae), tamarind (Tamarindus indica), Java olive tree (Sterculia foetida) and jujube red date (Ziziphus jujuba) (Aqualdo and Malantino 2014).

Another area that dominates is the tropical monsoon forest which is located 500-700 m asl. Some tropical community activities depend on the wet-dry season, especially in the Asian monsoon climate (Opaev et al. 2021). Monsoon forests have an important role in maintaining the microclimate, especially during the dry season in regard to fluctuations in rainfall and fires (Hamilton et al. 2020). The species of plants found in the monsoon forest include Kusum tree (Schleichera oleosa), Jujube red date (Ziziphus jujuba), banyan tree (Ficus sp.), noni (Morinda citrifolia), gebang palm (Corypha utan) and luwi (Alstonia scholaris). Komodo National Park also has highland forests. The forest, which is located above $700 \mathrm{~m}$ 
asl, has flora such as Calophyllum spectabile, Colona kostermansiana, Glycosmis pentaphylla, Purple aril mischocarp (Mischocarpus sundaicus), Mountain teak (Podocarpus neriifolius), Mengge (Terminalia zollingeri), Torres Strait scambler (Uvaria rufa), rattans (Calamus sp.), bamboo (Bambuseae). In addition, in Komodo National Park there are also about 30 species of orchids. The most dominant type of orchid is the Dendrobium orchid with white and orange flowers. Orchids in mountain forests usually live as epiphytes, but in Komodo National Park, two species of amoeboid orchids are found, namely Nervilia aragona and Nervilia $\mathrm{sp}$. which has a tuber-like part under the ground and during the rainy season will release dormant leaves (Witomo et al. 2020). In Komodo National Park, the diversity of mangrove species found in bays protected by waves is also very diverse. Several species of vegetation, namely Rhizophora sp., Rhizophora mucronata and Lumnitzera racemosa which are the 3 dominant species of mangrove vegetation. In addition, other species of mangrove vegetation such as Avicennia marina, Bruguiera sp., Capparis sepiaria, Ceriops tagal and Sonneratia alba (Got 2013).

\section{PARTIES INVOLVED IN KOMODO NATIONAL PARK}

The communities living in the Komodo National Park area and its surroundings act as first-time occupants along with their origin history (Naufal 2019). During the early stages of determining the Komodo National Park as a protected area, the Ministry of Forestry and international institutions did not properly disseminate information to village communities in the area (Hironimus et al. 2019). In fact, the community here is an important component in supporting protected areas because the people whose livelihoods depend on the area are not expected to damage or even threaten the fauna in the area, including Komodo dragons. There are currently three villages located within Komodo National Park; (i) Pasir Panjang Village (Kampung Rinca and Kampung Kerora), (ii) Komodo Village (Kampung Komodo), and (iii) Papagarang Village (Kampung Papagarang). The people have been living inside the park for centuries and have been preserving the environment of the dragons' habitat (KSDAE 2021).

Komodo National Park is responsible for the management of the protected areas since the determination of the KNP area in 1980 through the UPT (Technical Implementation Unit) for Natural Resources Conservation. All aspects regarding the national park are managed by the national park authority, even if there are other parties such as the private sector or investors. Temporary permit (contract permit) might be issued to private sectors to participate in the management of the KNP area through the enactment of government regulation No. 36 of 2010 concerning the Natural Tourism Concession Permit (IPPA).

Komodo National Park in its area has tourist destinations that are integrated into selected tour packages by tour operators in order to become an attraction for tourists from abroad and domestic. This is inseparable from the role of the West Manggarai Tourism and Culture Office which coordinates tourism on the West Manggarai District to manage tourism within the Komodo National Park area to accommodate the increasing number of tours and tourists. Thus, the Komodo National Park tourism programs are only related to increasing tourists and collecting data on tourist destinations within the Komodo National Park area (Lukita and Sunarto 2018).
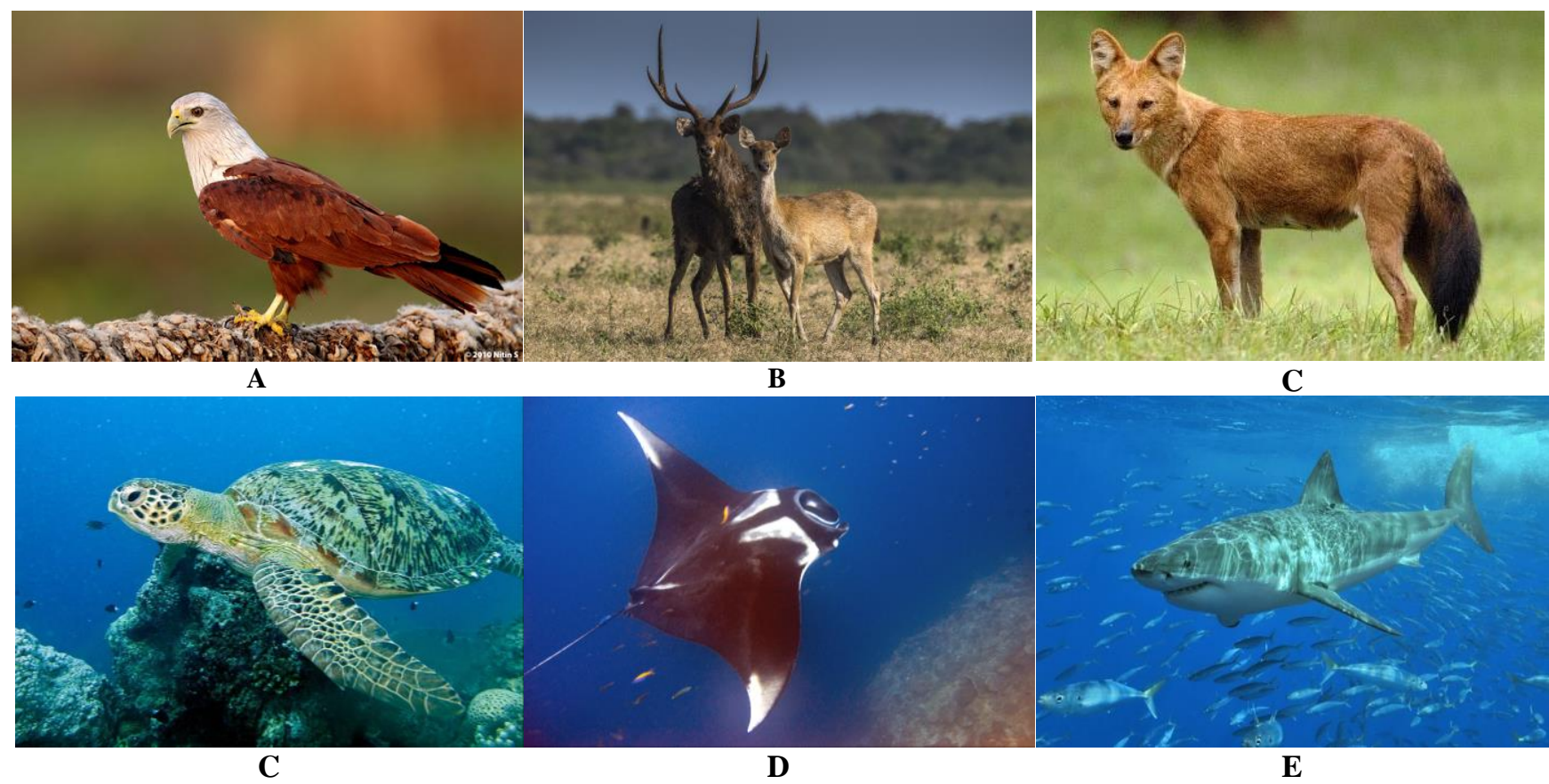

Figure 7. Some impressive fauna of Komodo National Park, Indonesia. A. Haliastur indus, B. Cervus timorensis, C. Cuon Alpinus, D. Chelonia mydas, E. Mobula birostris, F. Carcharodon carcharias (Photos from many sources) 


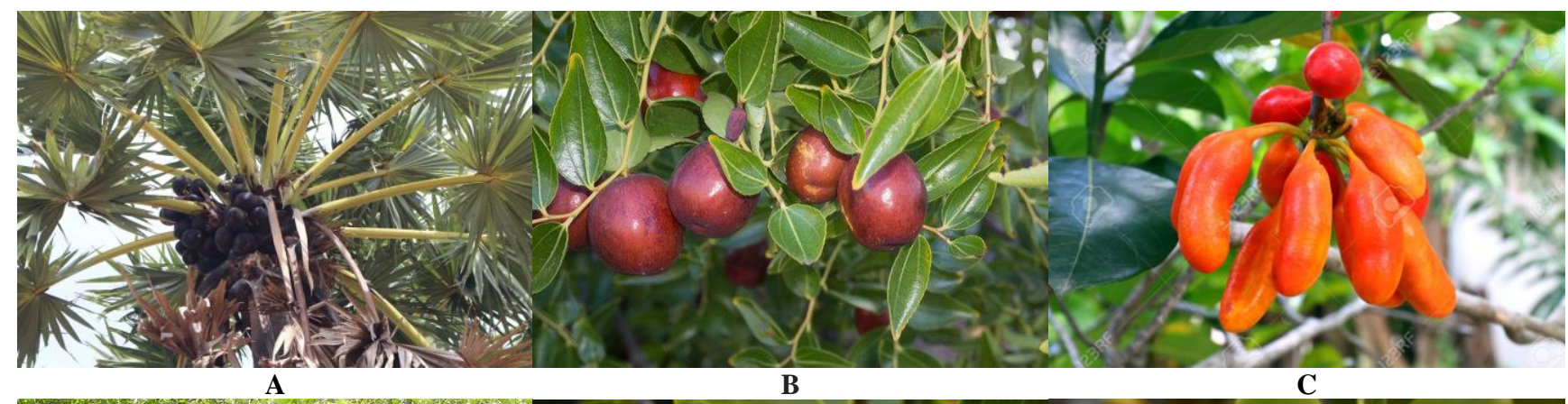

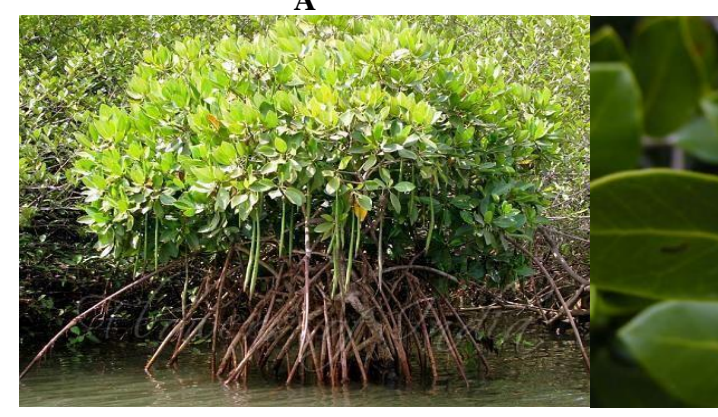

D

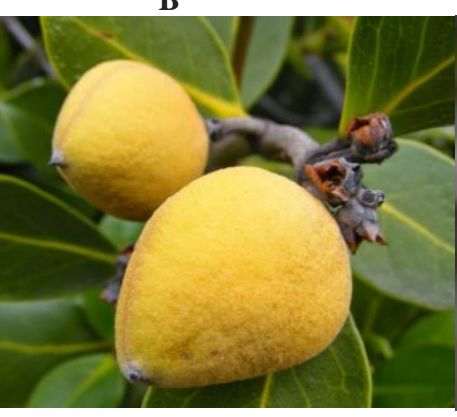

$\mathbf{E}$

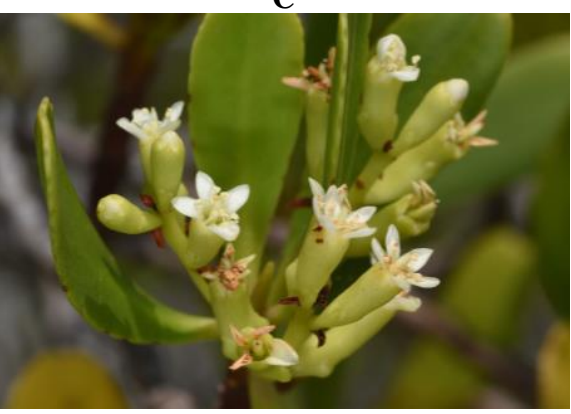

$\mathbf{F}$

Figure 11. Some plant species of Komodo National Park, Indonesia. A. Borassus flabellifer. B. Ziziphus jujuba, C. Uvaria rufa, D. Rhizophora mucronata, E. Avicennia marina, F. Lumnitzera racemosa

The phenomenon of changes in the livelihoods of the Komodo Island community cannot be separated from the intentional element of the government that regulates and supervises the KNP area into a resource based on natural tourism (Kiwang and Arif 2020). For example, when the existing resources have been used as objects of tourism attraction, then the people of Pasir Panjang Village are involved in gaining access to tourism resources such as Bat islands and Strawberry islands around the Pasir Panjang Village area. Thus, community involvement in the area has the ability to gain access to the benefits of tourism resources at the village scale (Michael 2009).

By regulation, natural resource management at the village scale must be managed professionally by establishing legal institutions recognized by the State through Village-Owned Enterprises (BUMDes) (Sembiring 2017). The prevailing regulations regarding village-scale resource management are implemented by village communities in the Komodo National Park area. The community is aware of the potential of natural resources owned by the village and the willingness of the community to take resource management by forming institutions through BUMDes. The village community in the Komodo National Park area deeply regrets the BUMDes institution which is expected to improve the welfare of the community but always conflicts with the rules of the Komodo National Park. One of them is an effort to maintain access to village tourism resources for the welfare of the community through BUMDes. On the other hand, there is awareness from village youth in Komodo Village and Pasir Panjang Village to form a tourism-aware community. This tourism-aware community wants to be better sheltered by BUMDes, a village tourism business division, both from the community in the area and the private sector with regard to maintaining access to village-scale resources. The ability to maintain access is carried out through the BUMDes institution by the community in the area. The role of community actors in the area is trying to maintain the usefulness of tourism resources through legal regulations in accordance with the law applicable to village laws (Puspitasari 2016).

There are useful suggestions for the development of ecotourism in Komodo National Park in Komodo Village, including the following: (i) To the managers of the National Park Authority to continue carrying out more vigorous promotions about the natural charm of Komodo National Park, improve the quality of information services about KNP and develop the existing tourism potential. In addition, for its preservation, attention must be paid to its impact on the economic growth of the Komodo Village community, in this case, the community can benefit directly from the development of ecotourism itself. (ii) To the government to continue to improve and develop infrastructure and tourism supporting facilities in the KNP area and in Labuan Bajo as the main entrance to Komodo National Park (Putra and Parno 2018).

\section{BARRIERS OF KOMODO NATIONAL PARK}

Indonesia is an archipelagic country and located in the equator, between two oceans and two continents so that it has a diversity of rainfall, temperature, humidity and wind direction (Kasa and Gunam 2019). The Komodo National Park ecosystem is influenced by the climate resulting from 
a long dry season, high air temperatures and low rainfall. In addition, Komodo National Park is located in a transitional zone between Asian and Australian flora and fauna (Wallacea Zone) (Fisher et al. 2020). Its aquatic ecosystem is affected by the El-Nino/La Nina impact, resulting in warming of the surrounding seawater and frequent strong ocean currents. The various types of ecosystems and habitats that Indonesia has created an amazing diversity of species and endemism (Keong 2015). However, the rapid and extensive loss of habitat, together with climate change become threats and create significant risks to biodiversity (Purwandana et al. 2014).

Increased tourist visits can also be a threat to the sustainability and diversity of the Komodo National Park area resources (Lasso and Dahles 2020), especially marine resources, so it is necessary to arrange the allocation of marine space to protect marine resources and ecosystems, as well as to utilize the potential marine resources in the Komodo National Park KSN. The presence of human settlements in the Komodo dragon's habitat has led to increased interactions between the two which can be negative. Negative interactions or commonly referred to as conflicts are interactions that are detrimental to one or both of the interacting parties. Conflict can occur because of competition between the two parties in utilizing the same resources and space (Luo 2007). Human-komodo conflicts are found in various areas within KNP and Flores Island, especially in areas with high populations of humans and Komodo dragons. Human-komodo conflicts that occur include Komodo attacks on humans, Komodo dragon attacks on livestock, and human attacks on Komodo dragons (Endo 2013). Wild animal attacks on livestock are one of the most common types of human-wildlife conflict (Karanth et al. 2012). The case of attacks by Komodo dragons has become a concern and has sparked concern among villagers in KNP and Flores. The existence of Komodo dragons in the village is often considered a threat and cases of attacks by Komodo dragons are often the reason for villagers to expel, capture, or even kill Komodo dragons (Sudibyo 2019). Komodo dragons are hunted by residents using dogs, caught with traps and bait, and even killed by poisoning (Gustaman 2020). However, since KNP was established in 1980 as a conservation area and the Komodo dragon was designated as a protected animal, cases of hunting, catching and killing of Komodo dragons are no longer found in KNP areas as reported by KNP Office in the statistics on types of disturbance in KNP areas during 2007-2012 (BTNK 2013). The expulsion of the Komodo dragon is still being carried out. Villagers used to use wooden sticks and pelt stones to repel Komodo dragons that entered the village (Sunkar et al. 2020).

Another obstacle factor in the development of ecotourism in Komodo National Park is the lack of community participation in tourism development (Benu et al. 2020). Minimal public participation can occur due to limited budgets, apathy and low public awareness, fluctuations in tourist visits, and difficulties in marketing ecotourism products. In an effort to overcome these barriers, communication between park managers and local communities is essential (Ormsby and Kaplin 2005).
Communication has 3 main indicators, namely: transmission, clarity of communication and consistency of communication. The communication transmission in question is the process of distributing information about a matter from the Head of the Tourism Office to the head of the tourism section and to the community. Clarity of information plays an important role in supporting the smooth flow of information between the Head of the Tourism Office as a policymaker and its parts and the community as policy implementers. Communication consistency will help the communication delivered by the Tourism Office so that the public can easily understand it. The recipients of communication, namely the community, can also understand the intent and purpose being discussed. The consistency of communication can prevent confusion from the Tourism Office in the field. Based on the observations of researchers, the information submitted by the Department of Tourism and Culture is one form of tourism object development coupled with support from local governments, stakeholders and related agencies, which are very influential in the activities carried out. Forms of support from the West Manggarai District government is evident in the construction of conference halls, boat bridges, and infrastructure improvements (Idris and Destari 2019).

\section{COMMUNITY-BASED TOURISM DEVELOPMENT STRATEGY}

The sustainability of ecotourism in protected areas needs to be considered in its development. Several factors that influence the development of ecotourism in protected areas including tourism potential maintained by the community can empower the surrounding community to manage tourist areas, and ecotourism activities that do not negatively impact the environment (Wulandari and Sunarto 2013). These negative impacts can be in the forms of pollution, damage to the physical environment, exploitation of resources and construction of facilities without considering the environmental conditions (Hijriati and Mardiana 2014). The development of ecotourism in protected areas must pay attention to the condition of the protected area. The pattern of spatial use that will be applied must be adapted to the conditions of the protected area (Zambrano 2010). In addition, the accessibility and safety of ecotourism development for protected areas must also be considered. The use and development of ecotourism in protected areas must pay attention to the activities that will be carried out by tourists (Hearne and Santos 2005). Thus, it can minimize the impact caused by these activities. Protected areas as ecotourism areas are permitted because protected forests are high in biodiversity, beautiful, and have diverse landscapes that can become tourist attractions and protect the protected areas (Lelloltery et al. 2020).

The current management of tourism in Komodo National Park (KNP) is through an ecotourism approach. KNP tourism activity is an ecotourism activity related to the Komodo dragon species and its biodiversity (Sulaeman et al. 2019). Good tourism management applies when the 
tourism sector can provide benefits to the whole community. This can be seen when small businesses in the community are involved in the tourism industry. Ecotourism was born as a form of protest against the model of mass tourism development with an emphasis on environmental conservation, cultural preservation, community participation, economic benefits, and empowerment of vulnerable groups (Cobbinah 2015). Ecotourism has the characteristics of managing landscapes and endangered species directed to resource conservation, community cultural management is directed to community welfare, and conservation activities are directed to efforts to maintain the continuity of resource use for the present and the future (Yustinaningrum 2017). Community participation is important in order to benefit from ecotourism development (Damanik 2013; Moscardo et al. 2017). Ecotourism development must be led by the local government which is part of the development vision. However, it does not rule out the possibility of conflict from the government and local communities, strict regulations, and environmental degradation (Lee and son 2017). Conflicts usually occur when services and facilities do not make local people and tourists comfortable (Ogucha et al. 2016). The involvement of local communities should start from planning to providing facilities and implementing ecotourism properly (Koens et al. 2009) in the end by forming good institutions that will produce sustainable tourism.

The community of Komodo Village is currently participating in the development of ecotourism in Komodo Island. The participation of the Komodo Village community in the development of ecotourism on Komodo Island cannot be separated from various factors that affect the Komodo Village community itself. Various forms of community participation in Komodo Village in the development of ecotourism in Komodo Island provide various benefits to the people of Komodo Village (Umar 2016). The participation of the Komodo Village community in the ecotourism business, for example as a dragon sculpture craftsman, selling souvenirs, naturalist guides, managing homestays, and renting motorboats. The participation of the Komodo Village community in conservation, namely by being involved in the Forestry Police Partner Community group and Conservation Cadre. Community-based tourism is an important component in the development of sustainable tourism (Asriyani and Verheijen 2020). One of the important elements in sustainable tourism development is careful and effective management of tourism destinations. In ensuring the sustainability of community-based tourism and its tourist attraction in the form of daily social and cultural activities from the community, ideally, it is also supported by safe and comfortable tourism destinations (Sin and Minca 2014). A tourism destination is a stage for the performance of all tourism resources that provide final value for tourist satisfaction. Therefore, the management of tourism destinations will determine the following three elementary things; a) the advantages and attractiveness of a destination for the tourist market; b) the level of benefits ecologically, economically, socially and culturally for the region; c) its competitiveness among international tourism destination markets (Damanik 2013).

The Komodo National Park tourism development strategy is carried out with community-based tourism (CBT). This approach will place the community as the main actor in tourism development that can minimize the negative impact of tourism development that relies on outside parties (Baksh et al. 2012; Hidrawati et al. 2019). Zoning provides guidance on the implementation of conservation strategies in Komodo National Park. As a conservation area, Komodo National Park is only occupied by officers from the Komodo National Park Office. Since it was opened for tourism activities, interactions that may be carried out in Komodo National Park are only limited to tourists buying souvenirs made by local people (Gabur and Sukana 2020). Another strategy implemented in Komodo National Park is holding tourism awareness counseling to the community to increase public understanding of the importance of conservation, then increasing supervision of illegal fishing. In addition, the Komodo National Park community can create distinctive products, collaborate with various competent parties in tourism, such as travel agents, tourism organizations, NGOs and the government (Sanjaya 2018).

Tourism has an impact on foreign exchange earnings, government revenues, prices, distribution of benefits, employment opportunities, ownership and control (Mbaiwa 2003). As the results of the study of the positive impact of the "hot spring" tourist attraction in Marobo with tourism activities, employment opportunities for the surrounding community are also created which can benefit local communities, development in general, and community income (Pieda and Anom 2019). This impact becomes an idea to create a flow of tourism development in an area. Tourism development must be carried out through: (i) Promotion, which is the implementation of marketing efforts that must be carried out in an integrated manner both at home and abroad; (ii) Accessibility, is one of the important supporting aspects because it involves crosssectoral development; c) Tourism area. These three will be a solution in developing aspects of tourism in Indonesia.

The development of community-based tourism in Komodo National Park has various potentials that are ideal for maximizing it in the form of an action plan, including several obstacles to formulating appropriate and effective strategies. Strategy is a process of determining the value of choices and making decisions in the use of resources that creates a commitment for the organization concerned to actions that lead to the future (Kanom and Zazilah 2019). Strategy can also be interpreted as an integrative general plan designed to empower tourism organizations to achieve their goals through the proper use of resources despite encountering many obstacles from competitors. Development is a process, method, act of making something better, advanced, perfect and useful. Development is a process/activity to promote something that is considered necessary to be arranged in such a way by rejuvenating or maintaining what has been developed to become more attractive and developing (dos Anjos and Kennell 2019). One of the most important things in 
developing an area into a tourism destination is analyzing and assessing internal and external environmental conditions, which include strengths, weaknesses, opportunities and threats (SWOT analysis). By knowing these conditions development can be carried out properly (Kanom 2015). SWOT analysis can be used as a model in analyzing a profit-oriented and non-profit-oriented organization with the main objective of knowing the state of the organization more comprehensively (Fahmi and Yunus 2013).

\section{Participation of ecotourism actors in conservation efforts}

When ecotourism development in Komodo National Park is implemented, it is considered to be a threat to the site. Pressures on the area such as garbage, pollution, collection of biological resources by visitors, vandalism and so on often accompany tourism development (Nepal 2000). Heny et al. (2013) stated that community participation in development is important because basically, the community knows best what is needed. In principle, community participation, especially in the development of tourist villages, is participation in managing resources in their environment (Batt 2009). One example is participating in keeping the environment clean or the cleanliness of the river means having participated in the preservation of wildlife. Keeping the natural environment clean is the same as maintaining the natural habitat of the wild animals themselves (Zulfa 2015). The existence of local communities has positively impacted forest sustainability (Badola et al. 2012). Local communities have understood the importance of the existence of forests for the lives of surrounding communities, so that community dependence, especially in collecting forest resources, is low and can be controlled (Ginting et al. 2010). Community participation can provide a strong impetus for resource protection in tourism areas (Wang and Tong 2009).

The participation of the people of Komodo Village in the development of ecotourism on Komodo Island has a positive impact on the maintenance of land and marine ecosystems around Komodo Island. The Komodo Village community actively participates in environmental conservation efforts by being involved in the Forestry Police Partner Community and Conservation Cadre (Ziku 2015). The definition of MMP as summarized in the Regulation of the Minister of Forestry of the Republic of Indonesia concerning Community Forestry Police Partners, Chapter I, Article 1 paragraph 4, is a community group around the forest that assists the Forestry Police in implementing forest protection under the coordination, guidance and supervision of the supervisory agency. Generally, communities empowered as MMPs are people living around forests or protected areas (Irfan 2018). The task of the Komodo Village MMP is to carry out land and sea security and provide understanding for the community both inside and outside the area related to zoning. A conservation cadre is a person who has been given education or who has been designated as the successor of natural resources conservation efforts who have awareness and knowledge of natural resources, and is voluntary, willing and able to convey conservation messages to the surrounding community. Through the Komodo National Park, the government empowers the people of Komodo Village as Conservation Cadres. KNP establishes and provides guidance related to environmental conservation to Conservation Cadres on a regular basis. Increasing community participation needs to be encouraged through several strategies including community capacity building, regional planning, financing, infrastructure development, institutional development and marketing (Kurniasari et al. 2013).

In conclusion, Komodo National Park covers land area of more than 603 square kilometers and 1214 square kilometers of marine habitat with high diversity. The land habitats have 277 species of animals, including 32 species of mammals, 128 birds, and 37 species of reptiles. The marine habitats have 253 species of corals, more than 1,000 species of fish, and 25 species of whales and dolphins. One of the main attractions of the Komodo National Park area is the ancient giant reptile of the Komodo dragon (Varanus komodoensis). Komodo dragon is top predator with the dominant prey species such as deer, wild boar and buffalo. Anthropogenic activities such as poaching can reduce the Komodo dragon population outside and inside the Komodo National Park area. Ecotourism is the right solution to protect endangered species that will become extinct. The participation of the people of Komodo Village in the ecotourism business, namely as craftsmen of Komodo statues, selling souvenirs, naturalist guides, managing homestays, and renting motorboats, can increase local economics and conservation awareness; as well as the participation of the Komodo Village community in conservation, such as being involved in the Forestry Police Partner Community group and Conservation Cadre. Meanwhile, the factors that hinder community participation in tourism development are limited budget, apathy and low public awareness, fluctuations in tourist visits, and difficulties in marketing ecotourism products.

\section{ACKNOWLEDGEMENTS}

We extend our sincere thanks to friends, colleagues, and reviewers who made this publication possible.

\section{REFERENCES}

Adil A, Triwijoyo BK. 2017. Analisa spasial sebaran pemukiman di Pulau Rinca (Kawasan Taman Nasional Komodo). Sentia 7 (2): C30-C34. [Indonesian]

Adil A. 2018. Perancangan spasial pengembangan potensi produk kerajinan berbasis pemukiman di Taman Nasional Komodo. MATRIK: Jurnal Manajemen, Teknik Informatika dan Rekayasa Komputer 18 (1): 50-57. DOI: 10.30812/matrik.v18i1.353. [Indonesian]

Ahmad R, Yunita RD. 2019. Ketidakadilan gender pada perempuan dalam industri pariwisata Taman Nasional Komodo. Jurnal Sosiologi Pendidikan Humanis 4 (2) : 84-93. [Indonesian]

Anshori F. 2005. Studi Variasi Komposisi Cetacea di Perairan Taman Nasional Komodo, Flores, Nusa Tenggara Timur. [Skripsi]. Fakultas Perikanan dan Ilmu Kelautan, Universitas Diponegoro, Semarang. 
Aqualdo N, Malantino RA. 2014. Analisis Dampak Ekonomi Obyek Wisata terhadap Pendapatan Masyarakat Lokal Studi Kasus Taman Nasional Bukit Tiga Puluh (TNBT) Kabupaten Indragiri Hulu. [Disertasi]. Universitas Riau, Riau. [Indonesian]

Ardiantiono, Jessop TS, Purwandana D, Ciofi C, Imansyah MJ, Panggur MR, Ariefiandy A. 2018. Effects of human activities on Komodo dragons in Komodo National Park. Biodivers Conserv 27: 3329-3347. DOI: $10.1007 / \mathrm{s} 10531-018-1601-3$

Ariefiandy A, Purwandana D, Coulson G, Forsyth DM, Jessop TS. 2013. Monitoring the ungulate prey of the Komodo dragon Varanus komodoensis: Distance sampling or faecal counts?. Wildl Biol 19 (2): 126-137. DOI: 10.2981/11-098

Ariefiandy A, Purwandana D, Natali C, Imansyah MJ, Surahman M, Jessop TS, Ciofi C. 2015. Conservation of Komodo dragons Varanu komodoensis in the Wae Wuul nature reserve, Flores, Indonesia: A multidisciplinary approach. Intl Zoo Yearb 49 (1): 67-80. DOI 10.1111/izy.12072

Ariefiandy A, Purwandana D, Azmi M, Nasu SA, Mardani J, Ciofi C, Jessop TS. 2021. Human activities associated with reduced Komodo dragon habitat use and range loss on Flores. Biodivers Conserv 30 461-479. DOI: 10.1007/s10531-020-02100-8

Asriyani H, Verheijen B. 2020. Protecting the Mbau Komodo in Riung, Flores: Local adat, national conservation and ecotourism developments. For Soc 4 (1): 20-34. DOI: 10.24259/fs.v4i1.7465

Badola R, Barthwal S, Hussain SA. 2012. Attitudes of local communities towards conservation of mangrove forests: A case study from the east coast of India. Estuar Coast Shelf Sci 96: 188-196. DOI: 10.1016/j.ecss.2011.11.016.

Baksh RS, Hakim L, Nugroho I. 2012. Community participation in the development of ecotourism: A case study in Tambaksari Village, East Java Indonesia. J Basic Appl Sci Res 2 (12): 12432-12437.

Balai Taman Nasional Komodo (BTNK). 2013. Statistik Balai TN Komodo tahun 2013. Balai Taman Nasional Komodo, Labuan Bajo. [Indonesian]

Balai Taman Nasional Komodo. 2018. Laporan Kinerja Balai Taman Nasional Komodo. Balai Taman Nasional Komodo, Labuan Bajo.

Batt S. 2009. Human attitudes towards animals in relation to species similarity to humans: A multivariate approach. Biosci Horiz: Intl J Stud Res 2: 180-190. DOI: 10.1093/biohorizons/hzp021

Benu F, Muskanan MW, King PG, Asa HM, Wulakada HH. 2020 Community participation and sustainable tourism development model in Komodo National Park. J Environ Manag Tourism 2 (42): 250-262. DOI: $10.14505 /$ jemt.v11.2(42).03.

Borchers H. 2008. Dragon tourism revisited: The sustainability of Tourism Development in Komodo National Park. In: Hitchcock M, King VT, Parnwell M (eds.). Tourism in Southeast Asia: Challenges and New Directions. University of Hawai'i Press, USA.

Budhianti MI. 2019. Perlindungan dan pengelolaan lingkungan hidup terkait pemanfaatan ruang untuk taman nasional. Supremasi Hukum 15 (1): 40-62. DOI: 10.33592/jsh.v15i1.245. [Indonesian]

Bull JJ, Jessop TS, Whiteley M. 2010. Deathly drool: Evolutionary and ecological basis of septic bacteria in Komodo dragon mouths. PloS One 5: e11097. DOI: 10.1371/journal.pone.0011097.

Butarbutar R, Soemarno. 2013. Environmental effects of ecotourism in Indonesia. J Indones Tour Dev Stud 1 (3): 97-107.

Butchart SHM, Brooks TM, Davies CWN, Dharmaputra G, Dutson GCL, Lowen JC, Sahu A. 1996. The conservation status of forest birds on Flores and Sumbawa, Indonesia. Bird Conserv Intl 6: 335-370. DOI: 10.1017/s0959270900001817.

Cobbinah PB. 2015. Contextualising the meaning of ecotourism. Tour Manag Perspect 16: 179-189. DOI: 10.1016/j.tmp.2015.07.015.

Damanik J. 2013. Pariwisata Indonesia: Antara Peluang dan Tantangan. Pustaka Palajar, Yogyakarta. [Indonesian]

Darsiharjo D. 2016. Konsep penataan ruang situ bagendit sebagai kawasan wisata alam dengan fungsi lindung di Kabupaten Garut. Jurnal Manajemen Resort dan Leisure 13 (1): 1-12. DOI: 10.17509/jurel.v13i1.2017. [Indonesian]

Davis RA, Doherty TS, van Etten EJB, Radford JQ, Holmes F, Knuckey C, Davis BJ .2016. Conserving long unburnt vegetation is important for bird species, guilds and diversity. Biodiv Conserv 25: 2709-2722. DOI: $10.1007 / \mathrm{s} 10531-016-1196-5$.

Djuanda TD. 2009. Potensi Mamalia Besar Sebagai Mangsa Komodo (Varanus omodoensis Ouwens 1912) di Pulau Rinca Taman Nasional Komodo, Nusa Tenggara Timur. [Hon Thesis]. Institut Pertanian Bogor, Bogor. [Indonesian] dos Anjos FA, Kennell J. 2019. Tourism, governance and sustainable development. Sustainability 11 (16): 4257 . DOI: $10.3390 /$ su 11164257

Endo H. 2013. Difficulties of conservation of the komodo monitors related to tourism and local economics in the eastern region of Indonesia. Jpn J Zoo Wildl Med 18 (1): 29-32. DOI: 10.5686/jjzwm.18.29.

Estoque RC, Estoque RS, Murayama Y. 2012. Prioritizing areas for rehabilitation by monitoring change in Barangay-based vegetation cover. ISPRS Intl J Geo-Inf 1: 46-68. DOI: 10.3390/ijgi1010046.

Fahmi I, Yunus M. 2013. Manajemen Strategis: Teori dan Aplikasi. Alfabeta, Bandung. [Indonesian]

Gabur MFA, Sukana M. Manajemen pariwisata di Pulau Padar, Taman Nasional Komodo, Labuan Bajo. Jurnal Destinasi Pariwisata 8(2): 336-342. DOI: 10.24843/jdepar.2020.v08.i02.p23. [Indonesian]

Fisher MR, Verheijen B, Sahide MAK. 2020. Community and conservation in Wallacea: Making the case for the region, a methodological framework, and research trends. For Soc 4 (1): 1-19. DOI: $10.24259 /$ fs.v4i1.9569.

Garsetiasih R. 2001. Daya dukung satwa herbivora (Rusa, Kuda, dan Kerbau) di Pulau Rinca Taman Nasional Komodo. Buletin Plasma Nutfah 7 (1): 22-25. [Indonesian]

Gibson E, Stacey N, Sunderland TCH, Dedi S, Adhur DS. 2020. Dietary diversity and fish consumption of mothers and their children in fisher households in Komodo District, eastern Indonesia. PLoS One 15 (4): e0230777. DOI: 10.1371/journal.pone.0230777.

Ginting Y, Dharmawan AH, Sekartjakrarini S. 2010. Interaksi komunitas lokal di Taman Nasional Gunung Leuser. Soladity: Jurnal Transdisiplin Sosiologi, Komunikasi dan Ekologi Manusia 4 (1): 3958. [Indonesian]

Got N. 2013. Eksostisme Taman Nasional Komodo. Jurnal Kepariwisataan 7 (2) : 1-22. [Indonesian]

Gustaman B. 2020. Menelusuri jejak dan rupa 'spesies selebritis' visualisasi ekspedisi-ekspedisi perburuan Varanus komodoensis 19121939. Jurnal Sejarah 3 (2): 7-27. DOI: 10.26639/js.v3i2.272. [Indonesian]

Hamilton R, Penny D, Hall TL. 2020. Forest, fire \& monsoon: investigating the long-term threshold dynamics of south-east Asia's seasonally dry tropical forests. Quat Sci Rev 238: 106334. DOI: 10.1016/j.quascirev.2020.106334

Hearne RR, Santos CA. 2005. Tourists' and locals' preferences toward ecotourism development in the Maya Biosphere Reserve, Guatemala. Environ Dev Sustain 7 (3): 303-318. DOI: 10.1007/s10668-004-29443

Heny, Made UD, Fandeli C, Baiquni M. 2013. Pengembangan desa wisata berbasis partisipasi masyarakat lokal di desa wisata Jatiluwih Tabanan, Bali. Kawistara 3 (2): 129-139. DOI: 10.22146/kawistara.3976. [Indonesian]

Hidrawati, Udu S, Manan A, Sahari S, Fyka SA. 2019. Strategi pengembangan pariwisata berbasis masyarakat (Studi Kasus di Perkampungan Wisata Sousu, Kabupaten Wakatobi). Jurnal Ilmiah Membangun Desa dan Pertanian 5 (3): 87-95. DOI: 10.37149/jimdp.v5i3.12028. [Indonesian]

Hijriati E, Mardiana R. 2014. Pengaruh ekowisata berbasis masyarakat terhadap perubahan kondisi ekologi, sosial dan ekonomi di Kampung Batusuhunan, Sukabumi. Jurnal Sosiologi Pedesaan 2 (3): 146-159. DOI: 10.22500/sodality.v2i3.9422. [Indonesian]

Hironimus YS, Rijanta R, Iskandar DA. 2019. Faktor-faktor yang mempengatuhi peran aktivitas pariwisata di Taman Nasional Komodo terhadap pertumbuhan ekonomi wilayah Kabupaten Manggarai Barat. Region: Jurnal Pembangunan Wilayah dan Perencanaan Partisipatif 14 (2): 141-153. [Indonesian]

Hutton J, Dickson B. 2000. The Past, Present and Future of CITES, the Convention on International Trade in Endangered Species of Wild Fauna and Flora. Earthscan, New York.

Idris MH, Destari R. 2019. Pengaruh destinasi pariwisata Pulau Komodo terhadap beberapa aspek pembangungan di Kabupaten Manggarai Barat. Jurnal Ilmu Administrasi Publik 7 (1): 56-68. DOI: 10.31764/jiap.v7i1.776. [Indonesian]

Imran AN. 2012. Identifikasi kapasitas komunitas lokal dalam pemanfaatan potensi ekowisata bagi pengembangan ekowisata di Kawah Cibuni. J Reg City Plan 23 (2): 85-102. DOI: 10.5614/jpwk.2012.23.2.1. [Indonesian]

Indrawati A, Edrus IN, Hadi TA. 2020. Karakteri struktur komunitas ikan karang target dan indikator di perairan Taman Nasional Komodo. Jurnal Penelitian Perikanan Indonesia 26 (2): 75-92. DOI: 10.15578/jppi.26.2.2020.75-92 
Irfan. 2018. Pemberdayaan Masyarakat Pulau Komodo Pasca Pembatasan Zona Wilayah Perairan Taman Nasional Komodo di Kabupaten Manggarai Barat. [Hon. Thesis]. Universitas Muhammadiyah Makassar, Makassar. [Indonesian]

Iriyono S, Syari' fudin, MI, Kurniawan M, Adnan A, Indriasari D, Buaith A, Margaretha PN. 2013. The assessment of Komodo National Park's role in the economics of West Manggarai Regency Nusa Tenggara Timur Province (Development of Ecotourism Utilization Aspect Case Study). Komodo National Park Office, Labuan Bajo.

IUCN. 2014. The IUCN Red List of Threatened Species, Retrieved 2/09/2016, 2016, http://www.iucnredlist.org

Jamu ME. 2014. Studi pengaruh experiential marketing terhadap kunjungan ulang pada daya tarik wisata Pulau Komodo, Manggarai Barat, Flores, Nusa Tenggara Timur. [Hon Thesis]. Fakultas Ekonomi, Universitas Sanata Dharma, Yogyakarta. [Indonesian]

Jessop TS, Madsen T, Ciofi C, Imansyah MJ, Purwandana D, Rudiharto H, Arifiandy A, Phillips JA. 2007. Island differences in population size structure and catch per unit effort and their conservation implications for Komodo dragons. Biol Conserv 135: 247-255. DOI: 10.1016/j.biocon.2006.10.025

Jessop TS, Forsyth DM, Purwandana D, Seno A. 2006. Efektivitas Penggunaan Metode Penghitungan Kotoran Untuk Menilai Distribus dan Kelimpahan Relatif Monyet dan Musang di Taman Nasional Komodo, Indonesia. Labuan Bajo, Flores, Indonesia. [Indonesian]

Jones AR, Jessop TS, Ariefiandy A, Brook BW, Brown SC, Ciofi C, Benu YJ, Purwandana D, Sitorus T, Wigley TML, Fordham, DA. 2020. Identifying island safe havens to prevent the extinction of the World's largest lizard from global warming. Ecol Evol 10 (19): 10492-10507. DOI: $10.1002 /$ ece 3.6705

Kanom, Zazilah AN. 2019. Strategi Pengembangan Pariwisata Berbasis Masyarakat di The Mandalika Kuta Lombok. Jurnal Binakwaya 14 (4): 2509-2524. [Indonesian]

Kanom. 2015. Strategi Pengembangan Kuta Lombok sebagai Destinasi Pariwisata Berkelanjutan. Universitas Udayana, Denpasar. [Indonesian]

Karanth KK, Gopalaswamy AM, DeFries, Ballal R. 2012. Assessing patterns of human-wildlife conflicts and compensation around a Central Indian protected area. PLoS ONE 7 (12): e50433. DOI: 10.1371/journal.pone.0050433.

Kasa IW, Gunam IBW. 2019. Menyimak penomena pemanasan global/perubahan iklim (La-Nina), alih fungsi lahan dan mitigas kerusakan lingkungan di Pulau Bali. Symbiosis 7 (2): 1-9. DOI: 10.24843/jsimbiosis.2019.v07.i02.p01

Kennedi UK, Kusrini MD, Ariefiandy A, Mardiastuti A. 2020. Invasive toads are close to but absent from Komodo National Park. BIO Web of Conf 19: 00017. DOI: 10.1051/bioconf/20201900017.

Keong CY. 2015. Sustainable resource management and ecological conservation of mega-biodiversity: The Southeast Asian big-3 reality. Intl J Environ Sci Develop 6 (11): 876-882. DOI: 10.7763/IJESD.2015.V6.715.

Kiwang AS, Arif FM. 2020. Perubahan sosial ekonomi masyaraka Labuan Bajo akibat pembangunan pariwisata. Gulawentah: Jurnal Studi Sosial 5 (2): 87-97. DOI: 10.25273/gulawentah.v5i2.7290. [Indonesian]

Kodir A, Tanjung A, Sumarmi, Ahmad R, Simanjutak TB. 2019. Tourism governance in Komodo National Park, Indonesia: Blessing or curse. GeoJ Tour Geosit 27 (4): 1401-1417. DOI 10.30892/gtg.27424-443.

Koens JF, Dieperink C, Miranda M. 2009. Ecotourism as a developmen strategy: experiences from Costa Rica. Environ Dev Sustain 11: 12251237. DOI 10.1007/s10668-009-9214-3.

KSDAE. 2021. Komodo National Park. Balai Taman Nasional Komodo, Labuan Bajo, Manggarai Barat.

Kurniasari E, Rustiadi E, Tonny F. 2013. Strategi pengembangan ekowisata melalui peningkatan partisipasi masyarakat, studi kasus komunitas kelurahan Kalimulya kota Depok. Jurnal Manajemen Pembangunan Daerah 5 (2): 32-47. DOI 10.29244/jurnal_mpd.v5i2.24637. [Indonesian]

Kurniawati R, Ratunnisa Z. 2016. Persepsi wisatawan terhadap atraksi wisata Animal Watching di Taman Nasional Komodo. Jurnal Destinasi Kepariwisataan Indonesia 1: 1-24. [Indonesian]

Kusnanto, Benu YJ, Kefi A. 2018. Kolaborasi Patroli Laut Dalam Upaya Pengawasan Lokasi Dive Site Hiu dan Pari Manta di Taman Nasional Komodo. Prosiding Simposium Nasional Hiu Pari Indonesia ke-2. Jakarta, 28-29 Maret 2018. [Indonesian]
Lasso AH, Dahles H. 2020. A community perspective on local ecotourism development: Lessons from Komodo National Park. Tour Geogr 1-21. DOI: 10.1080/14616688.2021.1953123

Lee JH, Son YH. 2017. Time series analysing stakeholder subjectivity in Maha ecotourism site in Pyeongchang, Korea. Spat Plan Sustain Dev 5 (2): 47-59.

Leha E, Wolo D, Rahmawati AS, Kean YYW. 2021. Survey kriteria standar usaha 7 lokasi wisata di Kabupaten Manggarai Barat tahun 2019. Mitra Mahajana: Jurnal Pengabdian Masyarakat 2 (2): 105-116. DOI: 10.37478/mahajana.v2i2.820. [Indonesian]

Lelloltery H, Hitipeuw JC, Sahureka M. 2020. Strategi pengembangan ekowisata berbasis masyarakat di hutan lindung Gunung Sirimau Kota Ambon. Jurnal Hutan Tropis 8 (1): 23-35. DOI: 10.20527/jht.v8i1.8155. [Indonesian]

Liestiandre HK, Mertha IW, Mahadewi NME, Tirtawati NM. 2019. Tourists' willingness to pay for destination quality improvement in Komodo National Park. J Adv Res Dyn Control Syst 11: 376-381

Lukita A, Sunarto S. 2018. Peran kementerian pariwisata dalam mengkampanyekan Taman Nasional Komodo melalui brand pesona indonesia. Prologia 1 (1): 1-6.

Lun FNG. 2016. Pengaruh Motivasi dan Disiplin Kerja terhadap Kinerja Pemandu Wisata (Guide) di Loh Liang dan Loh Buaya Kawasan Taman Nasional Komodo. [Thesis]. Universitas Terbuka Jakarta, Jakarta.

Luo Y. 2007. A coopetition perspective of global competition. J World Bus 42: 129-144. DOI: 10.1016/j.jwb.2006.08.007

Mayasari O. 2006. Perancangan Lansekap Resort Wisata Alam Loh Liang Taman Nasional Komodo NTT. [Hon. Thesis]. Fakultas Arsitektur Lansekap dan Teknologi Lingkungan, Universitas Trisakti, Jakarta.

Mbaiwa JE. 2003. The socio-economic and environmental impacts of tourism development on the Okavango Delta, north-western Botswana. J Arid Environ 54: 447-467. DOI: 10.1006/jare.2002.1101

Michael M. 2009. Community Involvement and Participation in Tourism Development in Tanzania: A Case Study of Local Communities in Barabarani Village, Mtowa Mbu, Arusha-Tanzania. [Thesis]. Victoria University of Wellington, New Zealand.

Mokodongan B, Sela R, Karongkong HH. 2014. Identifikasi pemanfaatan kawasan bantaran sungai Dayanan di Kotamobagu. Sabua: Jurnal Lingkungan Binaan dan Arsitektur 6 (3) : 273-283.

Moscardo G, Elena K, Laurie M, Nancy GM, Andrea S. 2017. Linking tourism to social capital in destination communities. J Destination Marketing Manag 6: 286-295. DOI: 10.1016/j.jdmm.2017.10.001

Murphy JB, Ciofi C, de La Panouse C, Walsh T. 2002. Komodo Dragons: Biology and Conservation. Smithsonian Institution, United States.

Muslich M, Priyono P. 2005. Penyebaran dan karakteristik sarang berbiak komodo (Varanus komodoensis Ouwens, 1912) di Loh Liang Pulau Komodo Taman Nasional Komodo Nusa Tenggara Timur. Media Konservasi 10 (1): 13-20.

Narulita S, Kosmaryandi N, Rachmawati E. 2012. Planning Interpretation Trail in Padar Island, Komodo National Park. [Skripsi]. IPB University, Bogor.

Naufal MI. 2019. Akses Masyarakat Terhadap Sumberdaya Pariwisata dalam Kawasan Taman Nasional Komodo, Kabupaten Manggarai Barat. [Skripsi]. Universitas Airlangga, Surabaya.

Nepal SK. 2000. Tourism in protected areas: The Nepalese Himalaya. Ann Tour Res 27: 661-681. DOI: 10.1016/S0160-7383(99)00105-X

Nurinsiyah DN, Gunawan B, Husodo T, Uchiyama T. 2015. Ecotourism development in Indonesia: A case study in Kawah Putih, West Java. J Rural Probl 51 (3): 197-202. DOI: 10.7310/arfe.51.197

Ogucha EB, Riungu GK, Kiama FK, Mukolwe E. 2016. The influence of homestay facilities on tourist satisfaction in The Lake Victoria Kenya Tourism Circuit. J Ecotour 4 (2): 278-287. DOI: 10.1080/14724049.2015.1105811

Oktaviani D, Sulaiman PS, Puspasari R. 2021. The vulnerability of reef fishes to environmental exposure in Komodo National Park and its surrounding waters. IOP Conf Ser Earth Environ Sci 805: 012014. DOI: 10.1088/1755-1315/805/1/012014

Opaev A, Gogoleva S, Palko I, Rozhnov V. 2021. Annual acoustic dynamics are associated with seasonality in a monsoon tropical forest in South Vietnam. Ecol Indic 122 (107269): 1-7. DOI: 10.1016/j.ecolind.2020.107269

Ormsby A, Kaplin BA. 2005. A framework for understanding community resident perceptions of Masoala National Park, Madagascar. Environ Conserv 32: 156-164. DOI: 10.1017/S0376892905002146 
Parta IN. 2019. Strategi pemasaran paket wisata Pulau Komodo, oleh PT. Komodo Cipta Wisata Tour and Travel di Kuta Bali. Jurnal Riset Ekonomi Manajemen 2 (2): 24-34. DOI: 10.31002/rn.v2i2.1325

Pernetta AP. 2009. Monitoring the trade: Using the CITES database to examine the global trade in live monitor lizards (Varanus spp.). Jurnal Biawak 3 (2): 37-45.

Pieda GCDRC da, Anom IP. 2019. Dampak ekonomi pengembangan daya tarik wisata "Hot Spring" di Kecamatan Marobo, Kabupaten Bobonaro, Timor-Leste. Jurnal Destinasi Pariwisata 7 (2): 226-230. DOI: 10.24843/jdepar.2019.v07.i02.p03

Portia L, Ulfah H. 2019. Ekowisata sebagai Potensi Daya Saing Pariwisata di Indonesia. Proceeding of National Conference on Asbis. Politeknik Negeri Banjarmasin, Banjarmasin, 7 November 2019.

Pratiwi AD, Tungka AE, Lahamendu V. 2017. Strategi pengembangan kawasan ekowisata di Pulau Lembeh (Studi kasus: Kelurahan Paudean, Kelurahan Pasir Panjang dan Kelurahan Dorbolaang). Spasial 4 (3): 245-256.

Purwandana D, Ariefiandy A, Imansyah MJ, Rudiharto H, Seno A, Ciofi C, Fordham DA, Jessop TS. 2014. Demographic status of Komodo dragons populations in Komodo National Park. Biol Conserv 171: 2935. DOI: 10.1016/j.biocon.2014.01.017

Puspitasari IA. 2016. Partisipasi Masyarakat dalam Pengembangan Parawisata di Pulau Komodo Kabupaten Manggarai Barat Provinsi Nusa Tenggara Timur. [Hon Thesis]. Universitas Muhammadiyah Makassar, Makassar. [Indonesian]

Putra PSE, Parno R. 2018. Strategi pengembangan ekowisata Taman Nasional Komodo di Desa Komodo Nusa Tenggara Timur. In Seminar Ilmiah Nasional Teknologi, Sains, dan Sosial Humaniora (SINTESA) 1 (1):-. [Indonesian].

Ramadhan F. 2016. Pengaruh kualitas layanan dan promosi terhadap keputusan berkunjung ke tempat wisata Pantai Samudera Baru. Jurnal Manajemen 14 (1): 1894-1906. [Indonesian]

Reuleaux A, Siregar BA, Collar NJ, Panggur MR, Mardiastuti A, Jones MJ, Marsden SJ. 2020. Protected by dragons: Density surface modeling confirms large population of the critically endangered Yellow-crested Cockatoo on Komodo Island. The Condor 122 (4): 115. DOI: 10.1093/condor/duaa042.

Rijal S, Nasri N, Ardiansyah T, Chairil A. 2020. Potensi pengembangan ekowisata rumbia Kabupaten Jeneponto. Jurnal Hutan dan Masyarakat 12 (1): 1-13. DOI: 10.24259/jhm.v12i1.6031

Sanjaya RB. 2018. Strategi pengembangan pariwisata berbasis masyaraka di Desa Kemetul, Kabupaten Semarang. Jurnal Master Pariwisata 5 (1): 91-110. DOI: 10.24843/jumpa.2018.v05.i01.p05 . [Indonesian]

Safarabadi A. 2016. Assessing ecotourism potential for sustainable development of coastal tourism in Qeshm Island, Iran. Eur J Geogr 7 (4): 53-66.

Seifi F, Ghobadi GRJ. 2017. The role of ecotourism potentials in ecological and environmental sustainable development of Miankaleh protected region. Open J Geol 7: 478-487. DOI: 10.4236/ojg.2017.74033

Sembiring S. 2017. Keberadaan badan usaha milik desa dalam meningkatkan pendapatan asli desa. Kertha Patrika 39 (1): 16-31. DOI: 10.24843/kp.2017.v39.i01.p02. [Indonesian]

Sin HL, Minca C. 2014. Touring responsibility: The trouble with 'going local' in community-based tourism in Thailand. Geoforum 51: 96106. DOI: $10.1016 /$ j.geoforum.2013.10.004.

Situmeang IVO. 2012. Strategi humas dalam mempublikasikan pariwisata Pulau Komodo (studi pada Kementrian Kebudayaan dan Pariwisata). Komunikologi: Jurnal Ilmiah Ilmu Komunikasi 9 (2): 75-82. [Indonesian]

Sokhanvar A, Çiftçioğlu S, Javid E. 2018. Another look at tourismeconomic development nexus. Tour Manag Perspect 26: 97-106. DOI: 10.1016/j.tmp.2018.03.002

Sudaryanto S, Herdiansyah H. 2018. Keberlanjutan dan dampak jangka panjang operasi perikanan intensif di tempat pemijahan ikan baronang (Siganus canalicullat) di Pulau Papagaran-Taman Nasional Komodo. Ecotrophic 12 (2): 158-172. DOI: 10.24843/ejes.2018.v12.i02.p06. [Indonesian]
Sudibyo DL. 2019. Komodo dragon attacks: The changing of human and environment relations. Humaniora 31 (2): 142-151. DOI: 10.22146/jh.v31i1.42851.

Sulaeman D, Sjarmidi A, Iskandar DT. 2019. Professional management on ecotourism and conservation to ensure the future of Komodo National Park. Intl J Humanities Soc Sci 13 (9): 1245-1250. DOI: 10.5281/zenodo.3462057.

Sunkar A, Kusrini MD, Ramadhani FS. 2020. Role of culture in the emotional response towards komodo dragon in Komodo and Rinca Islands of Komodo National Park. Bio Web Conf 19: 00021. DOI: 10.1051/bioconf/20201900021.

Supriatna J, Wahyono EH. 2000. Panduan Lapangan Primata Indonesia. Yayasan Obor Indonesia, Jakarta. [Indonesian]

Suraji S, Hasan S, Suharyanto S, Yonvitner Y, Koeshendrajana S, Prasetiyo DE, Dermawan A. 2020. Nilai penting dan strategis nasional rencana zonasi kawasan Taman Nasional Komodo. Jurnal Sosial Ekonomi Kelautan dan Perikanan 15 (1): 15-32. DOI: 10.15578/jsekp.v15i1.8888. [Indonesian]

Suryani NLM, Noak PA, Yudhartha IPD. 2016. Analisis manajemen pengelolaan obyek wisata dalam mewujudkan pembangunan pariwisata yang berkelanjutan melalui badan usaha milik desa (BUMDA) (studi kasus obyek wisata Pantai Pandawa Kuta Selatan Kabupaten Badung). Citizen Charter 1 (1): 1-6

Susila IKEW, Pramono J. 2020. Pengelolaan Atraksi Wisata Ular Suci Daya Tarik Wisata di Pura Tanah Lot Tabanan Bali Indonesia. Seminar Ilmiah Nasional Teknologi, Sains, dan Sosial Humaniora (SINTESA). Universitas Dhyana Pura, Bali, 13 November 2020. [Indonesian]

Sutomo S. 2020. Vegetation composition of savanna ecosystem as a habitat for the komodo dragon (Varanus komodoensis) on Padar and Komodo Islands, Flores East Nusa Tenggara Indonesia. J Trop Biodivers Biotechnol 5 (1): 10-15. DOI: 10.22146/jtbb.48280.

Tapper R. 2006. Wildlife Watching and Tourism. United Nations Environment Programme (UNEP) and the Secretariat of the Convention on the Conservation of Migratory Species of Wild Animals (CMS), Bonn.

Umar. 2016. Peranan Partisipasi Masyarakat Desa Komodo dalam Pengembangan Ekowisata di Pulau Komodo Kabupaten Manggarai Barat-NTT [Hon Thesis]. Universitas Muhammadiyah Makassar, Makassar. [Indonesian]

Walpole MJ, Goodwin HJ, Ward KGR. 2008. Pricing policy for tourism in protected areas: Lessons from Komodo National Park, Indonesia. Conserv Biol 15: 218-227. DOI: 10.1111/j.1523-1739.2001.99231.x.

Wang H, Tong M. 2009. Research on community participation in environmental management of ecotourism. Intl J Bus Manag 4 (3): 131-135. DOI: 10.5539/ijbm.v4n3p131.

Witomo CM, Harahab N, Kurniawan A. 2020. Nilai manfaat pariwisata ekosistem terumbu karang taman wisata perairan Gita Nada Sekantong Lombok. Jurnal Sosial Ekonomi Kelautan dan Perikanan 15 (2): 169-184. DOI: 10.15578/jsekp.v15i2.9234. [Indonesian]

Wulandari TW, Sunarto. 2013. Pemanfaatan Kawasan Lindung untuk Ekowisata di Kecamatan Ngebel, Kabupaten Ponorogo. UGM Pers, Yogyakarta. [Indonesian]

Yilma ZA, Reta MM, Tefera BT. 2016. The current status of ecotourism potentials and challenges in Sheko District, South-Western Ethiopia. J Hotel Bus Manag 5 (2): 1000143. DOI: 10.4172/2169-0286.1000143

Yustinaningrum D. 2017. Pengembangan wisata bahari di taman wisata perairan pulau Pieh dan laut sekitarnya. Agrika: Jurnal Ilmu-ilmu Pertanian 11 (1): 96-111. [Indonesian]

Zambrano AMA, Broadbent EN, Durham WH. 2010. Social and environmental effects of ecotourism in the Osa Peninsula of Costa Rica: The Lapa Rios case. J Ecotour 9 (1): 62-83. DOI: 10.1080/14724040902953076.

Ziku RM. 2015. Partsipasi masyarakat Desa Komodo dalam pengembangan ekowisata di Pulau Komodo. Jurnal Master Pariwisata 2 (1): 1-21. DOi: 10.24843/jumpa.2015.v02.i01.p01. [Indonesian]

Zulfa, Vania. 2015. Hubungan kepedulian lingkungan dengan partisipasi pelestarian orangutan (Pongo Pygmaeus Linnaeus, 1760) pada masyarakat desa Tanjung Harapan Kalimantan Tengah. [Hon Thesis]. Universitas Negeri Jakarta, Jakarta. [Indonesian] 